TI 2011-068/2

Tinbergen Institute Discussion Paper

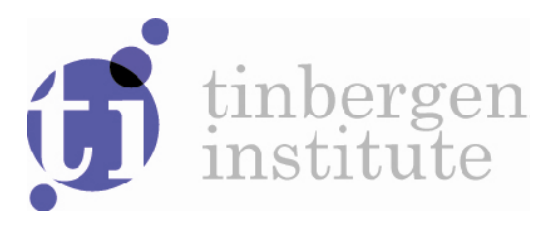

Fiscal Sustainability, Volatility and Oil Wealth:

A Stochastic Analysis of Fiscal Spending Rules

Sweder van Wijnbergen'

Nina Budina?

' Faculty of Economics and Business, University of Amsterdam, the Netherlands, and Tinbergen Institute;

2 IMF. 
Tinbergen Institute is the graduate school and research institute in economics of Erasmus University Rotterdam, the University of Amsterdam and VU University Amsterdam.

More TI discussion papers can be downloaded at http://www.tinbergen.nl

Tinbergen Institute has two locations:

Tinbergen Institute Amsterdam

Gustav Mahlerplein 117

1082 MS Amsterdam

The Netherlands

Tel.: +31(0)205251600

Tinbergen Institute Rotterdam

Burg. Oudlaan 50

3062 PA Rotterdam

The Netherlands

Tel.: +31(0)10 4088900

Fax: +31(0)104089031

Duisenberg school of finance is a collaboration of the Dutch financial sector and universities, with the ambition to support innovative research and offer top quality academic education in core areas of finance.

DSF research papers can be downloaded at: http://www.dsf.nl/

Duisenberg school of finance

Gustav Mahlerplein 117

1082 MS Amsterdam

The Netherlands

Tel.: +31(0)20 5258579 


\title{
Fiscal Sustainability, Volatility and Oil Wealth: A Stochastic Analysis of Fiscal Spending Rules
}

\author{
Sweder van Wijnbergen* \\ University of Amsterdam \\ and Tinbergen Institute \\ Nina Budina \\ IMF
}

April 2011

\begin{abstract}
Whether fiscal policy is sustainable depends on a government's future revenue and expenditure streams, both of which are highly uncertain. In commodity-rich countries, this problem is intensified by unpredictable and volatile commodity prices. We show how spending rules for oil income and non-oil primary deficits interact and influence the stochastic distribution of future debt stocks and demonstrate the variance reducing impact of feedback rules for primary deficits in a case study of oil-and-gas exporter Azerbaijan.
\end{abstract}

Key words: volatility, oil wealth, fiscal sustainability

* Forthcoming in Economics of Transition. Corresponding author S. van Wijnbergen, Email s.j.g.vanwijnbergen@uva.nl. We thank Christos Kostopoulos of the World Bank for many discussions on the Azerbaijan case study, and Alexander France (UvA), the editor and the two referees for their many constructive comments. 


\section{Introduction}

Commodity exporters face special macroeconomic problems for at least two reasons. First, resource income is highly volatile, ways will have to be found to isolate the economy from the consequences of that volatility. And two, resource based economies are likely to face major adjustment problems both at the beginning and at the end of their resource rich period. Extraction volumes are hump shaped over time in many countries, ramping up quickly but anticipated to end also in the foreseeable future. During the upswing, manufacturing industries come under pressure, as resources are drawn into the non-traded sector; but once resource income starts declining, those very manufacturing industries will be needed again to earn foreign exchange. This paper is about how fiscal policy can be used to manage both problems.

We use Azerbaijan as a case study. Azerbaijan is rapidly building up its production and export capacity, and can expect to be a substantial energy producer for some decades to come. Its situation is different from major oil exporters like Russia or Kazakhstan, however, in that oil and gas production is expected to peak in the coming five to ten years. Russia and Kazakhstan expect to remain major oil producers at least until the next century. At currently known reserve levels and production plans, Azerbaijan's revenues from oil and gas is expected to run out in twenty years. The temporary nature of oil and gas income in Azerbaijan gives rise to special concerns: the post-oil economy is more imminent than in countries that have enough oil reserves for the foreseeable future.

One approach to the humpshape problem is to limit expenditure out of oil revenue to levels that can be sustained indefinitely, the so called Permanent Income Equivalent Rule. This can be implemented by saving in high-revenue years through allocation to a dedicated Oil Fund (OF), and dissaving out of that OF in low-income years. Allocating the PI equivalent to the budget and saving oil and gas revenues in excess of that amount in an OF, would give the OF an extra function - that of smoothing out any unexpected change in income due to temporary and unanticipated price changes. Importantly, such an allocation should be accompanied by a limit on the non-oil primary deficit (NOPD), otherwise what is 
saved on the one hand, is dissaved on the other, thereby making the allocation to the OF ineffective.

The major difference with the existing literature ${ }^{1}$ is the extensive attention paid to uncertainty, both in the choice of discount rates, and the derivation of the entire distribution of possible future outcomes, instead of focusing on one, or a few, scenarios. This extension of the commonly used PI framework also allows for the explicit analysis of debt management policies designed to reduce volatility. We simulate likely debt stocks in the future under various policy rules for the non-oil deficits. In one scenario, the non-oil primary deficit $(N O P D)$ is limited to the calculated value of the permanent income equivalent of all current and future oil revenues. Additionally, the consequences of high spending and low oil prices are explored.

Moreover, we explicitly focus on uncertainty by deriving not just the expected value of future (net) debt stocks, but their entire distribution. This allows assessment of the probability that critical debt levels will be exceeded in future periods. The results reflect the high volatility of the Azeri economy: without active fiscal management of uncertainty, the likelihood of very high levels of net debt cannot be excluded unless the permanent income approach is followed, and even then exceeding critical debt levels remains possible. But we also show that an active debt management policy, in which debt shocks are followed by temporarily tighter fiscal policies, can greatly reduce the variance of future outcomes without increasing the expected burden of fiscal policy. Such fiscal feedback rules lower the chance that critical debt ratios will be exceeded and will thus lower the riskiness of the economic environment in Azerbaijan.

\section{Background: Azerbaijan}

\section{From Chaos to Oil Boom}

Following independence in 1991, Azerbaijan experienced massive terms of trade shocks, a disintegration of marketing and trading systems, and an end to Soviet era fiscal transfers and subsidies. The armed conflict with Armenia and the associated influx of about one million Azeri refugees have further aggravated the economic problems. Azerbaijan

\footnotetext{
${ }^{1} \mathrm{Cf}$ Collier et al (2010) for a recent interpretative survey, where volatility and uncertainty are not discussed at all.
} 
suffered an output collapse and entered the post-independence transition period considerably poorer than many other former Soviet republics.

Since 1995, the Azeri government embarked on a comprehensive stabilization and structural reform program. This reform program has been remarkably successful:

macroeconomic and financial stability have been restored and maintained throughout severe external shocks, such as the Russian financial crisis in 1998 and the large drops in oil prices in 1998 and 1999. The economic dependence on oil and gas increased substantially as a result of the rapid oil sector development. As a result, fiscal revenues from oil and gas exploration have become increasingly important sources of revenue; they increased from 8 percent of total revenue in 1998 to more than half of total revenue in 2006.

\section{Figure 1. Oil production profile}

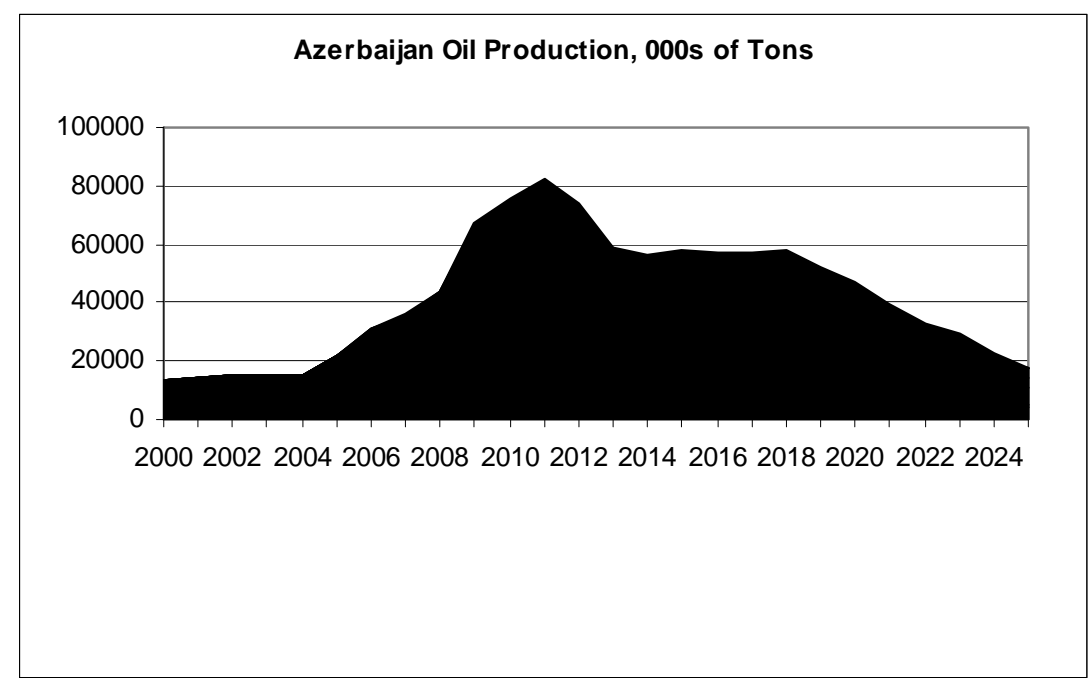

The contribution of the oil and gas sector to the economy will increase further as Azerbaijan is rapidly building up its production and export capacity, and can expect to be a substantial energy producer for decades to come. Azerbaijan's proven oil reserves are conservatively estimated at 900 million tons. However, absent any major new oil discovery, after peaking at 65 million tons in 2011, and followed by a relatively short plateau, production will decline rapidly to less than half its peak level by 2018 . Thereafter, it will wane to about a quarter of the peak level in 2024 (see Figure. 1).

This hump-shaped production profile will cause a similar pattern of rising, and then decreasing, oil revenues. Revenues from oil and gas extraction are divided between the oil 
companies and other contractors, as compensation for operating costs and for profit and capital repatriation, and the government as oil- related fiscal revenues. The latter consists of Oil Fund revenues and oil-related collections through the state budget, such as oil-related profit taxes. Assuming that oil prices will remain above $\$ 40-45$ per bbl during the next 20 years, oil and gas amount to at least $\$ 130$ billion, or about 15 times the 2006 non-oil GDP in constant US dollars. However, without any new oil/gas discoveries, oil revenues are projected to decline quickly afterwards, returning to their current levels by 2015 and disappearing altogether by 2025 .

The humped shape of oil revenues gives rise to a series of questions, both on intergenerational equity (How can generations that will come after the hump share in the oil wealth?), and on how Azerbaijan can adjust to a post-oil era. The creation of the Oil Fund, and the cautious approach that has been adopted for its use, enable a shift of some of the benefits to future generations while smoothing out oil-financed expenditure. This also pushes any post-oil adjustment problems further into the future. Moreover, an important advantage of the Oil Fund is that it separates the commercial decisions associated with oil extraction from public spending decisions, and provides an effective and convenient way to insulate the economy from the adverse effects of excessive and volatile oil revenues. ${ }^{2}$

\section{Oil Income Volatility}

Higher oil revenues have led to increased dependence on a highly volatile source of income. Two problems stand out: first, income volatility, and second, the exchange rate consequences of spending out of oil revenues. Oil revenues are highly volatile, even when quantities are relatively easy to predict: price volatility is high, making oil revenue an extremely uncertain source of income, even when production levels are relatively stable. In turn, high spending out of curent oil income translates income volatility into highly volatile expenditure, with potentially serious negative macroeconomic consequences.

The volatility of public spending has been low compared to the volatility of oil revenues: during 1995 -2000 the ratio of the volatility of public spending to the volatility of oil revenues was roughly 20 percent, and a higher but still modest 50 percent during 2001-

\footnotetext{
${ }^{2}$ The Oil Fund inflows consist of oil signature bonuses, the Government's share of profit oil, acreage fees, transit fees, rental fees and interest accruing to the Oil Fund's assets.
} 
2006, the beginning of the oil bonanza period. This is low compared to many other oil exporters; Nigeria is an extreme example, where the ratio has been above 1 during all of Nigeria's oil years (Budina and van Wijnbergen (2008)). Apparently the current fiscal framework has had some success in insulating public expenditure from oil income volatility.

\section{"Dutch Disease" issues}

High, and volatile spending out of oil revenues creates another problem. Increases in expenditure unavoidably fall, to a large extent, on goods and services where international trade offers only an imperfect substitute or none at all, such as construction. This, in turn, implies that high spending puts upward pressure on the prices of those goods and services, with a real appreciation as a result (van Wijnbergen (1984a,b)). Equally, high, volatility of spending will lead to high volatility of the real exchange rate. The authorities have no choice on the real exchange rate consequences, only on how they come about. This may have longterm consequences for growth, since exchange rate volatility is like a tax on investment. High volatility slows down productivity growth by a substantial margin, in particular in countries with relatively underdeveloped financial sectors (cf. Aghion ea (2009)).

In Azerbaijan, the situation is even more challenging, given the hump-shaped nature of the oil windfall: any appreciation is predictably going to be short-lived. Thus if the humpshaped nature in oil revenues translates in a humpshaped spending pattern, adjustment to the post-oil economy with once again a lower real exchange rate, becomes a serious issue too (cf Caballero (2007), who stresses that temporary booms may cause adjustment problems requiring policy interventions $\left.{ }^{3}\right)$. .

A real appreciation, unavoidable or not, always raises the issue of competitiveness and the survival of traditional manufacturing industries. Such diversification concerns are appropriate only when the appreciation is expected to be temporary. If expenditure is anticipated to decline in line with falling oil revenues in the near future, real exchange rate pressure will again subside. The case can be made that letting the T-sector go to waste in the meantime will lead to unnecessary adjustment problems now, and lost opportunities later, particularly in countries with weak financial intermediaries (Caballero 2007). If a country

\footnotetext{
${ }^{3}$ Van Wijnbergen (1984a) also argues that policy intervention is only justified if the boom is shortlived and capital markets are not used to smooth out expenditure.
} 
uses the PI approach, like Azerbaijan has done, spending out of oil revenues is set at levels that can be maintained once the oil runs out, by saving in high income years. Thus, expenditure does not need to decline once oil revenues run out and there will be no need for a future real depreciation at that time. That, in turn, means that keeping the T-sector alive through subsidies ("diversification policies") until the time the real appreciation is reversed, is not needed, as there will be no such reversal if the PI approach to spending out of oil revenues is followed.

\section{Fiscal Sustainability and Managing Oil Price Uncertainty}

Several empirical papers address fiscal sustainability in small oil exporting countries: cf. Tersman (1991), Liuksila, et al. (1994), Bascand and Razin (1997), Chalk (1998), Barnett and Ossowski (2002), Davoodi (2002), Baunsgaard (2003), and IMF (2003). These authors all use variants of the permanent income approach, which are expounded below. We extend the framework used in that literature by embedding it in a simulation approach to incorporate the uncertainty of oil prices, interest rates, and other relevant variables, while exploring budget rules designed to lower the variance of projected debt stocks. In particular, we explore error-correction types of policy reaction functions like the one described by Bohn (2007) as "more promising for understanding deficit problems."

Assessing fiscal sustainability for oil-rich countries requires distinguishing between the oil and non-oil fiscal deficits. Consider the various rules that are being used in practice to govern spending out of oil wealth. First, we should examine some accounting on oil and financial reserves. Oil reserves $\mathrm{S}_{\mathrm{t}}$ are depleted through extraction $\mathrm{O}_{\mathrm{t}}$ :

$$
S_{t}=S_{t-1}-O_{t}
$$

$$
\text { ignoring new discoveries, and }
$$

$$
\mathrm{F}_{\mathrm{t}}=(1+r) \mathrm{F}_{\mathrm{t}-1}+P_{t} O_{t}-P I_{t^{\prime}, t}
$$

Financial reserves $F_{t}$, possibly in an explicit Oil Fund, accumulate through interest earnings and revenues in excess of expenditure out of oil income. 
One approach to managing variable resource income is the consumption-smoothing or permanent income (PI) approach, under which a variable income stream is used to finance a constant stream of expenditure of equal net present value (NPV). Under that rule, expenses equal a constant (in real terms) amount: $P I_{t^{\prime}, t}=\overline{P I}_{t^{\prime}}$, for all future t. PI is now defined as the real infinitely sustainable expenditure level with the same discounted value as the flow of oil income (ignoring uncertainty, for the moment):

$$
\overline{P I}_{t^{\prime}, *}=r\left(F_{t-1}+\sum_{t=t^{\prime}}^{\infty}(1+r)^{-\left(t-t^{\prime}\right)} P_{t} O_{t}\right)
$$

The PI approach is also the framework adopted by the Oil Fund in Azerbaijan.

In practice, several other rules are used in resource-rich countries. An example is the bird-in-the-hand $(\mathrm{BIH})$ rule adopted by the Norwegian authorities: under that rule, spending out of oil income cannot exceed the investment income of the Oil Fund:

$$
B I H_{t^{\prime}, t}=r F_{t-1}
$$

The two rules yield the same outcome if oil revenues are projected to be zero from the date of implementation onwards: in that case, the PI rule calls for restricting expenditure to investment income also. In all other cases, the PI rule allows for higher expenditure because the PI equivalent of anticipated future oil revenues is added to the $\mathrm{BH}$ prescription, which only equals the PI prescription if only past oil revenues are taken into account:

$$
\begin{aligned}
\overline{P I}_{t^{\prime}, *}-B I H_{t^{\prime}, t} & =r\left(F_{t-1}+\sum_{t=t^{\prime}}^{\infty}(1+r)^{-\left(t-t^{\prime}\right)} P_{t} O_{t}\right)-r F_{t-1} \\
& =r \sum_{t=t^{\prime}}^{\infty}(1+r)^{-\left(t-t^{\prime}\right)} P_{t} O_{t}
\end{aligned}
$$

Another approach adopted in many countries, for example, by Kazakhstan and Russia, is the long run price (LRP) rule. Here, oil revenues are transferred to the Oil Fund, from which monies are transferred to the budget in an amount equal to what oil revenues would have been if a specified long run price would have prevailed. If actual prices exceed 
(fall short of) that "long run price", the fund accumulates (decumulates) assets in addition to its investment income. Spending under this rule equals:

$$
L P R_{t^{\prime}, t}=\bar{P}_{t^{\prime}} \cdot O_{t}
$$

Clearly, $\mathrm{LPR}_{\mathrm{t}, \mathrm{t}}=\mathrm{Pi}_{\mathrm{t}^{\prime}, \mathrm{t}}$ only when

$$
\begin{aligned}
& 1 / O_{t}=O_{t^{\prime}} \text { for all } t>t^{\prime} \\
& 2 / \sum_{\mathrm{t}=t^{\prime}}^{\infty}\left(\mathrm{P}_{\mathrm{t}}-P_{t^{\prime}}\right)(1+r)^{-\left(t-t^{\prime}\right)}=0 \\
& 3 / F_{t^{\prime}-1}=0
\end{aligned}
$$

There is no easy equivalence between PI and LRP outcomes unless oil production and extraction costs are essentially flat for the foreseeable future. For countries like Russia, with large proven oil and gas reserves, limiting budget transfers out of oil income to revenues calculated at a long-term average (reference) price rather than the current high price, has similar effects to the PI approach. Oil Stabilization Funds (OSFs) may be set up to save oil revenues above the expenditure levels allowed by whatever rule is adopted, although implementation of such spending rules is, in principle, not dependent on whether or not a separate entity for oil revenues is set up.

\section{Integrating an oil-spending rule into fiscal sustainability analysis}

We use a simple model to integrate these various rules into a fiscal sustainability framework. The model used below allows the user to choose between various rules. We then use simulation methods to forecast the distribution and evolution of net public debt/assets, accounting for the rules chosen for governing Oil Fund allocations, the non-oil primary deficit, and foreign debt accumulation. A schematic of the proposed framework is shown in Figure 2 below. It consolidates the government's fiscal accounts with an Oil Stabilization Fund $^{4}$ and the central bank's foreign currency reserves. Fiscal policy is captured by restrictions on the size of the non-oil primary deficit (NOPD) of the public sector, plus the rule for allocating current oil revenues from the OSF to the budget.

Fiscal sustainability analysis, then, means examining the impact of the non-oil primary fiscal deficit and OSF allocation rules on (the distribution of) future net debt levels,

\footnotetext{
${ }^{4}$ Although we refer to oil, any other natural resource can be substituted, like Chile's Copper Stabilization Fund.
} 
including monies saved in the OSF, under various scenarios for the oil price. We explicitly focus on the effects of uncertainty, not just through scenario analysis, but also through full stochastic analysis, allowing Value-at-Risk-like assessments and the impact of specific feedback rules on the volatility of future variables.

Figure 2. Fiscal Sustainability Framework for Oil-rich Countries.

$\begin{array}{ll}\text { Taxation Regime } \quad \text { Oil Price } & \text { Oil Production } \quad \text { Oil Reserves } \\ & \quad \text { Calculate }\end{array}$

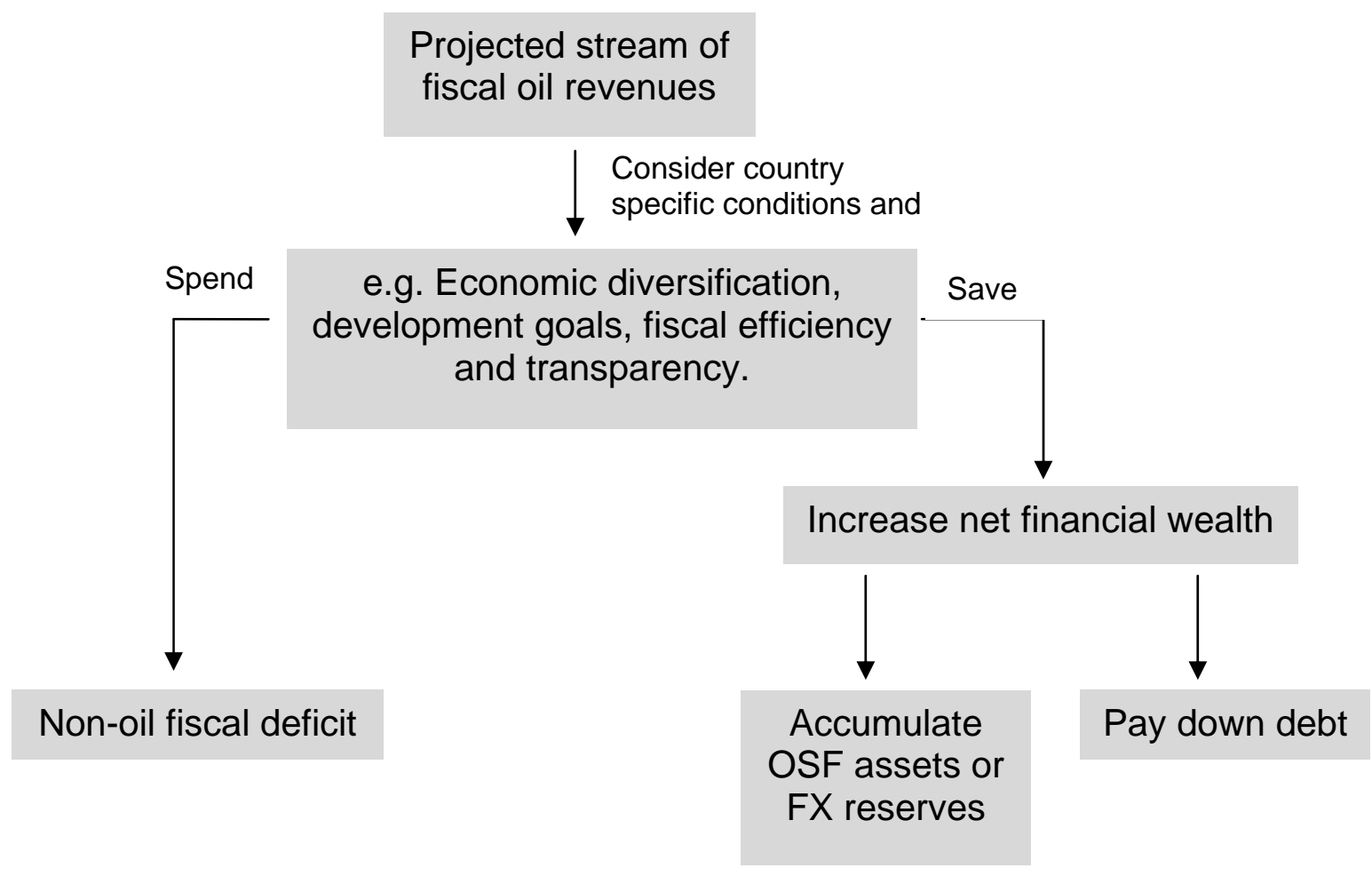

The traditional approach to fiscal sustainability asks whether current or planned primary fiscal balances (public revenues minus non-interest expenditure) are compatible with stable debt-to-GDP ratios, given interest rates, growth rates, and real exchange rate developments. Given the special features of the oil-rich countries noted above, managing volatility during oil price booms makes it advisable to divert at least some of the current oil revenues to an Oil Stabilization Fund (OSF), which many countries are doing today. Hence, 
the analysis needs to incorporate an OSF (or equivalent policy rules) and to consider an OSF allocation rule. Fiscal policy is captured by the limit on the non-oil primary deficit (NOPD) of the public sector and the OSF allocation rule. Fiscal sustainability analysis would then examine the impact of the non-oil primary fiscal deficit limit and the OSF allocation rule on net debt levels, after consolidating public debt with the OSF assets accumulated under various scenarios for the oil price.

The first step in such an approach is to create a baseline scenario of the likely future time path of the oil producer's net financial asset position, using the flow budget constraint equation. This equation updates future net financial assets as a share of GDP, using macroeconomic projections of key determinants of public debt dynamics, such as growth, inflation, projected primary surpluses, and interest rates. The baseline also includes projected oil and gas fiscal revenues, based on assumptions of remaining oil reserves, the future rate of oil extraction, future oil prices, and taxation regimes.

To ensure consistency among debt stocks, deficits, and revenue from seigniorage, it is necessary to consolidate the general government accounts with the central bank's profit and loss account (Anand and van Wijnbergen 1989). Otherwise, seigniorage, an important source of revenue in many developing countries, will not show up in the budget dynamics.

Moreover, debt may be mismeasured by failing to take into account assets held by the central bank. This is especially important if the savings from current oil revenues are deposited in the central bank. Public sector foreign debt is measured net of the (net) foreign asset holdings of the central bank and net of the assets of the Oil Fund, if those are deposited outside the central bank. Similarly, deficits and the ensuing liabilities for the state may be seriously mismeasured if the quasi-fiscal deficit of the central bank is excluded. Therefore, debt sustainability analysis based only on gross debt dynamics (e.g. IMF(2003), (2005)), disregarding other public sector assets or liabilities could be misleading.

After consolidation, increases in net public debt (measured net of the net foreign assets, public debt holdings of the central bank, and oil fund assets) can be decomposed in various contributing factors, which, in turn, can be linked to the available macroeconomic projections. After switching to ratios to GDP, public debt dynamics can be broken down into several components: (1) the primary fiscal deficit net of seigniorage revenues; (2) growthadjusted real interest rate payments on domestic debt; (3) the real cost of external borrowing, 
including capital gains and losses on net external debt due to changes in the real exchange rate; and (4) other factors:

$$
\dot{d}=(p d-\sigma)+(r-g) b+\left(r^{*}+\hat{e}-g\right)\left(b^{*}-n f a^{*}\right) e+O F
$$

Here, $d$ is the net public debt-to-GDP ratio (that is, measured net of the net foreign assets and public debt holdings of the central bank, and net of oil fund assets); $p d$ is the overall primary deficit as a share of GDP; $g$ is the real GDP growth rate; $r$ is the real interest rate on domestic debt, $r^{*}$ is the real interest rate on external debt; $e=E P^{*} / P$, with $e$ being the real exchange rate and obvious other definitions of variables; and $O F$ refers to other factors. OF collects residuals due to cross-product terms arising because of the use of discrete time data (see Bandiera e.a. (2007) for more complicated but essentially similar discrete time formulas). OF also includes debt-increasing factors that, in a perfect accounting world, would be included in deficit measures, but in the real world often are not. Examples include the fiscal consequences of a bank bailout, and one-off privatization revenues.

Given the special features of oil revenue, in particular, its exhaustibility and volatility, we incorporate the various non-oil deficit rules and Oil Fund spending rules separately in the public debt dynamics equation. We therefore break the overall primary deficit into two components: the non-oil primary deficit, NOPD, and the projected oil fiscal revenues, Roil:

$$
\dot{d}=(n o p d-\sigma)+(r-g) b+\left(r^{*}+\hat{e}-g\right)\left(b^{*}-n f a^{*}\right) e-R_{o i l}+O F
$$

To be meaningful at all, any Oil Fund accumulation rule should be complemented with targets for the non-oil deficit. Putting money aside with one hand, but borrowing simultaneously with the other, obviously would make the Oil Fund rule ineffective. For a better focus of the fiscal sustainability analysis on the interactions between the Oil Fund and non-oil deficit rules, we break down oil revenues Roil, into (i) oil revenue flowing into the budget, Roil $l_{s b}$, and (ii) net inflow in the oil fund osf. The latter clearly equals the difference between total oil revenue and the oil revenue flow to the budget: Roil- Roil $I_{s b}$. The dynamics of the oil fund are:

$$
\text { osf }=(r * \hat{e}-g) \text { osf } * e+\left[\text { Roil }- \text { Roil }_{s b}\right]
$$


With the assumption that the oil fund is invested in foreign assets osf*, inserting this into the general debt dynamics equation produces:

$$
\begin{aligned}
\dot{d}= & \left(\text { nopd }- \text { Roil }_{s b}-\sigma\right)+(r-g) b+\left(r^{*}+\hat{e}-g\right)\left(b^{*}-n f a^{*}\right) e \\
& -\left(r^{*}+\hat{e}-g\right) o s f * e-\left[\text { Roil }- \text { Roil }_{s b}\right]+O F
\end{aligned}
$$

This is the basic equation we will use in the simulations.

Introducing stochastic shocks and fiscal feedback rules

Of course most of the variables introduced in equations 1.6-9 are subject to shocks. Bohn (2007) has stressed the importance of fiscal feedback rules in a stochastic environment: he shows that even a small amount of feedback from debt surprizes to subsequent (partially) offsetting increases in the primary budget surplus are both necessary and sufficient for fiscal sustainability. Reverting for simplicity to a minimal discrete debt dynamics equation, we collapse all possible stochastic shocks into a single shock to the primary deficit $d_{t}$.

$$
\begin{aligned}
& b_{t}=d_{t}+(1+r) b_{t-1} \\
& d_{t}=\bar{d}_{t}+\varepsilon_{t} \\
& \quad \Rightarrow b_{t}=\bar{d}_{t}+\varepsilon_{t}+(1+r) b_{t-1}
\end{aligned}
$$

$\bar{d}_{t}$ is the non-stochastic part of the primary deficit process. Define $b_{t}^{\tau}$ as the (stochastic) projection of $b$, constructed at time $t$, for $\tau$ periods ahead. We show in Annex 1 that if the shocks to $d_{t}$ are i.i.d. with constant variance $\sigma$, the variance of this projection equals:

$$
\operatorname{var}\left(b_{t}^{\tau}\right)=\left(\frac{(1+r)^{2 \tau}-1}{(1+r)^{2}-1}\right) \sigma^{2}
$$

where we assumed a constant real rate of interest $r$, mostly to save on tedious but uninformative notation. Consider next a fiscal feedback rule as proposed by Bohn (2007):

$$
d_{t}=\bar{d}_{t}+\varepsilon_{t}-\gamma \varepsilon_{t-1}
$$


The primary surplus is subject to shocks, like in (1.10), but also contains a feedback reaction whereby a fraction $\gamma$ of the shock in the previous period is offset this period. It is straightforward to show that with such a fractional feedback rule the variance of future debtstocks will be reduced. Using the subscript "FR" and "NFR" for cases where there is respectively there is not such a feedback rule, we can show (see Annex 1):

$$
\operatorname{var}\left(b_{t}^{\tau}\right)_{F R}=(1-\gamma)^{2}\left(\frac{(1+r)^{2 \tau}-1}{(1+r)^{2}-1}\right) \sigma^{2}
$$

Combining (1.12) and (1.13) gives the desired result:

$$
\operatorname{var}\left(b_{t}^{\tau}\right)_{F R}=(1-\gamma)^{2} \operatorname{var}\left(b_{t}^{\tau}\right)_{N F R}
$$

Clearly a fractional offset coefficient $\gamma \subset(0,1)$ leads to variance reduction ${ }^{5}$.

\section{The Value of Oil Wealth and Sustainable Spending in Azerbaijan}

We demonstrate the impact of the various fiscal and oil fund rules using Azerbaijan as an example. We used available forecasts of oil and gas extraction rates, based on rich data on the costs in each individual oil field. After accounting for the tax structure, royalties, and production sharing schemes, we can specify the relationship between oil revenues and various oil price scenarios. Under baseline oil price assumptions, Azerbaijan will experience a very steep increase in oil fiscal revenues early on. However, without any new oil/gas discoveries, oil revenues are projected to decline quickly (cf. Fig.3 below)

\footnotetext{
${ }^{5}$ Actually $\gamma \subset(1,2)$ would also lead to variance reduction as can be seen from (1.14)), but also to presumably undesirable saw tooth patterns.
} 
Figure 3. Projected oil and gas extraction profile in Azerbaijan.

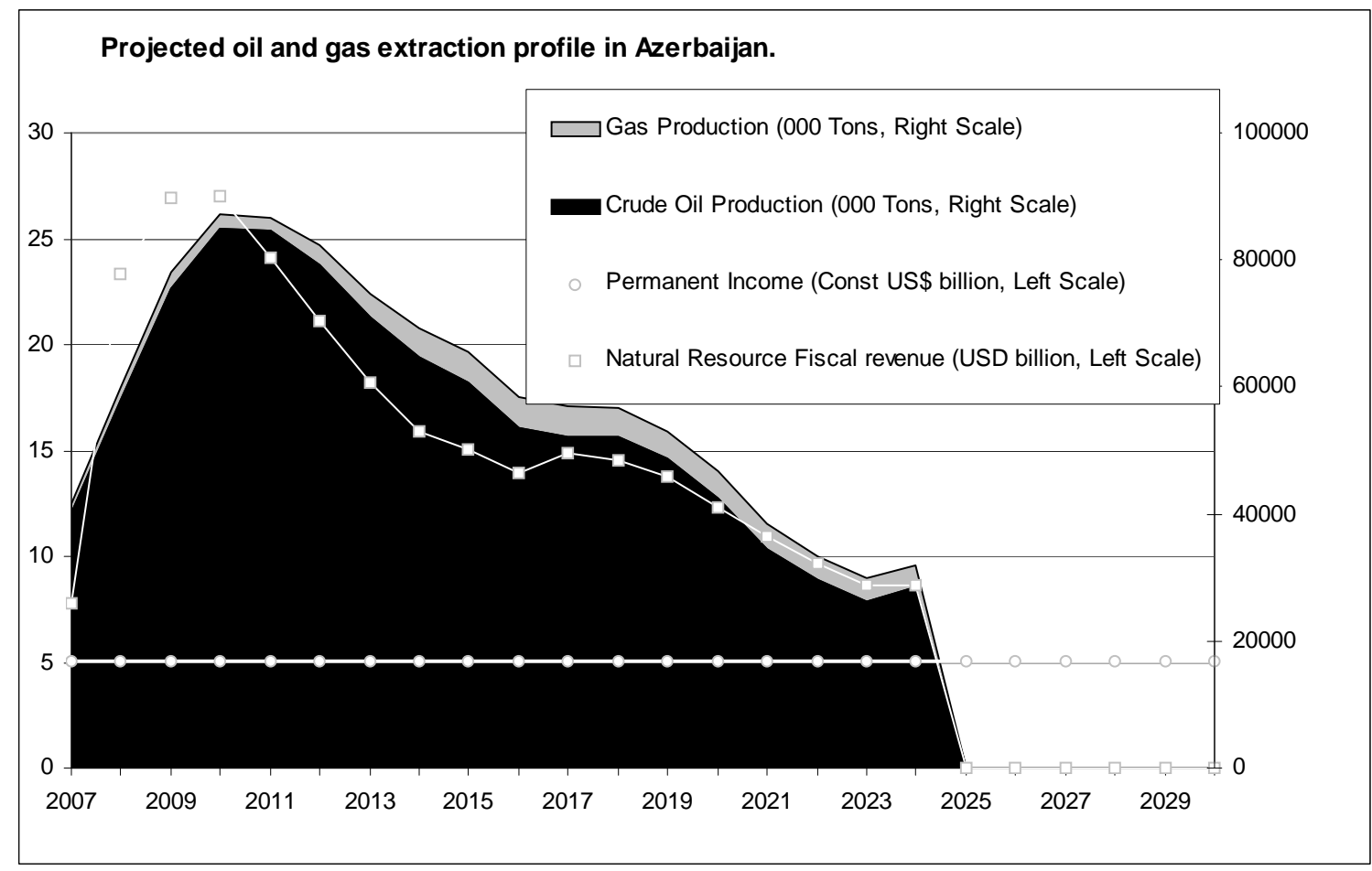

For different oil price scenarios, we have used two sets of World Bank's long-term oil prices forecasts - the latest available at the time the simulations were run (February 2008), and a previous vintage of price forecasts, referred as old oil price forecasts.

Figure 4 below lists both sets of oil price projections, and the associated projected fiscal revenues from oil \& gas production for the Azeri Government:

\section{Figure 4. Oil and Gas fiscal revenue projections}

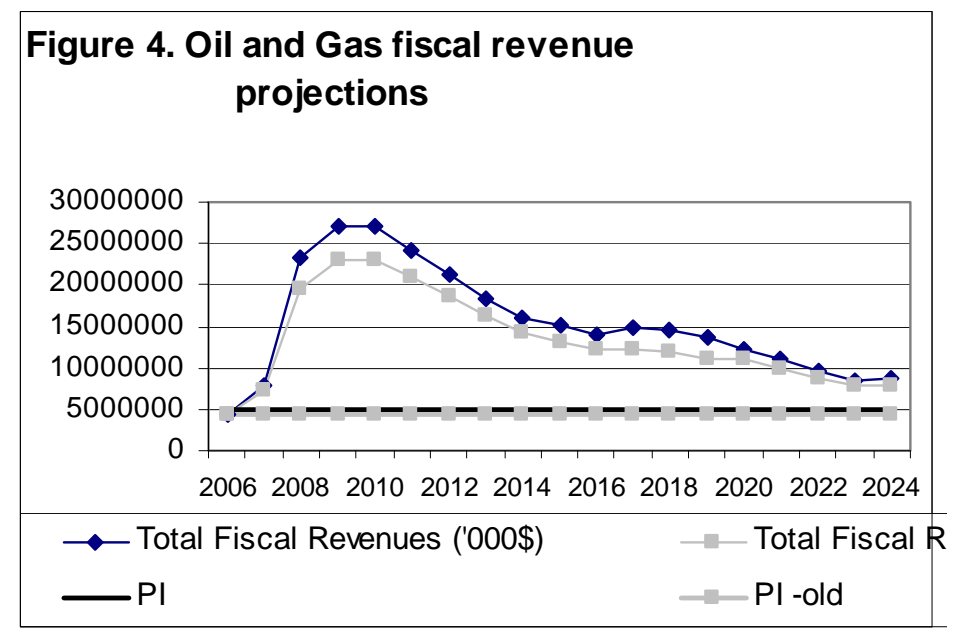

In table 1 below, we build up the NPV and PI calculation for Azerbaijan. We discount the future income back to 2007 in a net present value calculation, assuming a safe real rate of interest of $3 \%$ (equal to the US long-term real rate, plus a hundred basis points Azerbaijani country risk). This is added to the long-term US inflation projection of $2.4 \%$ as of Feb. 2008 to arrive at a safe 
nominal dollar rate of $5.5 \%$. But the income stream being discounted is not a safe one; it is shrouded in substantial uncertainty. To account for the riskiness, we add a $3 \%$ risk premium to the basic safe real rate (this is a departure from common practice in the PI approach applications).

Using the oil price forecast from Feb 2008, the NPV of the oil and gas wealth is estimated at US\$ 165 billion (nearly 6 and 15 times the 2007 GDP and non-oil GDP, respectively), higher than the NPV estimate under the older price forecasts. . The PI equivalent estimate, corresponding to this level of wealth (again using the safe real rate to discount a flow of income/expenditure that is constant in real terms), is 5 billion 2007 dollars (18 and 45 percent of 2007 GDP and non-oil GDP, respectively). The PI equivalent amount is what can be safely spent on an annual basis indefinitely, thus allowing future generations to share in equal, absolute, annual amounts (not per capita or as a share of their income).

Table 1. Permanent income approach to oil wealth (in const (2007) US\$ billion).

\begin{tabular}{lcccc}
\hline \multicolumn{1}{c}{ Oil Price Assumptions } & $\begin{array}{c}\text { Net wealth } \\
\text { US\$ billion }\end{array}$ & $\begin{array}{c}\text { Net oil wealth to } \\
\text { 2007 GDP (\%) }\end{array}$ & $\begin{array}{c}\text { Net oil wealth to 2007 } \\
\text { non-oil GDP, \% }\end{array}$ & $\begin{array}{c}\text { Annuity, in } \\
\text { US\$ 2007 billion }\end{array}$ \\
\hline \multicolumn{1}{c}{ Real Safe rate of interest =3\%, Risk premium=3\%, Foreign inflation=2.4\% } \\
$\begin{array}{l}\text { Old Oil Price } \\
\text { Assumptions }\end{array}$ \\
$\begin{array}{l}\text { New Oil Price } \\
\text { Assumptions (Feb. 2008) }\end{array}$ & 143 & 515 & 1274 & 4.4 \\
\hline
\end{tabular}

${ }^{1}$ This annuity can be interpreted as the sustainable level of annual spending.

Table 1 shows the different PI calculations compared to the two revenue forecasts. An increase of more than US\$20billion in oil wealth (NPV) results in an increase of less than US\$700 million of the spending limit because the windfall gain is spread out over the entire future. Of course, the increase in the spending limit is linked to world inflation. Hence, under the assumption of the old (lower) long-term oil price forecast, the NPV of the oil wealth is brought down to $\$ 143$ billion, 12.7 times non-oil GDP, while the corresponding permanent income equivalent is estimated at $\$ 4.4$ billion. 
Consider next the impact of the changes in the various components of the discount rates (Table 2 below). In the first row, we list the NPV and the spending level (constant in real terms over time) that yields the same NPV (the permanent income equivalent) for a basic safe rate of $3 \%$, and a risk premium also of $3 \%$. Lowering the risk premium has a substantial impact on the valuation of the uncertain income stream. In the extreme case of a zero risk premium, the NPV jumps from 165 to almost 195 billion US\$ and the PI equivalent goes up from 5.1 billion to 6 billion US\$. The cumulative difference between the PI without and with a risk premium (growing at close to $1 \mathrm{~B} \$$ /year) could be considered as the buildup of a buffer stock due to the risk aversion embedded in a risk premium.

Table 2. Sensitivity of Azerbaijan's Oil and Gas Wealth Estimates

Constant 2007 US\$ billion

\begin{tabular}{lr}
\hline & Estimate 1 \\
Real risk-free interest rate of 3 percent, risk premium of 3 percent \\
Net Present Value & 165 \\
PI equivalent & 5.1 \\
& \\
Estimate 2 & \\
Real risk-free interest rate of 3 percent, no risk premium & \\
Net Present Value & 6.0 \\
PI equivalent & \\
& \\
Real risk-free interest rate of 2 percent, no risk premium & \\
Net Present Value & 208 \\
PI equivalent & 4.3 \\
\hline Source: Author's calculations &
\end{tabular}

Lowering the discount rate itself has a different impact. Going to a safe rate of $2 \%$, at a zero risk premium, increases the NPV further, to 208 billion US\$. However, because the permanent income equivalent stream of expenditure is more stretched out towards the future than the actual income flows, , the impact of lower rates is more pronounced than on the more front-loaded profile of actual revenues. Therefore the discounted value of the constant expenditure stream goes up more than the NPV of the actual income stream. To restore equality, the expenditure flow needs to be lowered: the net impact of lower real rates is thus to decrease, rather than increase, the PI equivalent. 
The results from the permanent income calculations are presented in Figure 5. As shown in Figure 5, the permanent income out of the oil windfall -- calculated for projected oil prices, and serving as a low-case estimate for the historical average oil price of the past 20 -year period ( $\$ 25.5$ per bbl in const 2007 dollars) -- is between $\$ 3.8$ billion and $\$ 5.3$ billion in constant 2007 dollars, and a little bit higher in current dollars (fig.5). The permanent income levels shown in Fig. 5, when compared with actual revenues (cf fig.4) indicate that Azerbaijan, on this rule, should save substantial amounts of its oil revenues for the entire duration of the first half of this century. It also reveals that current levels of expenditure may be somewhat high, but are not very far out of line with what the PI approach would dictate, based on current wisdom, in terms of oil price projections, i.e., the World Bank oil price projections at the time.

\section{Figure 5. PI estimates and actual NOPD.}

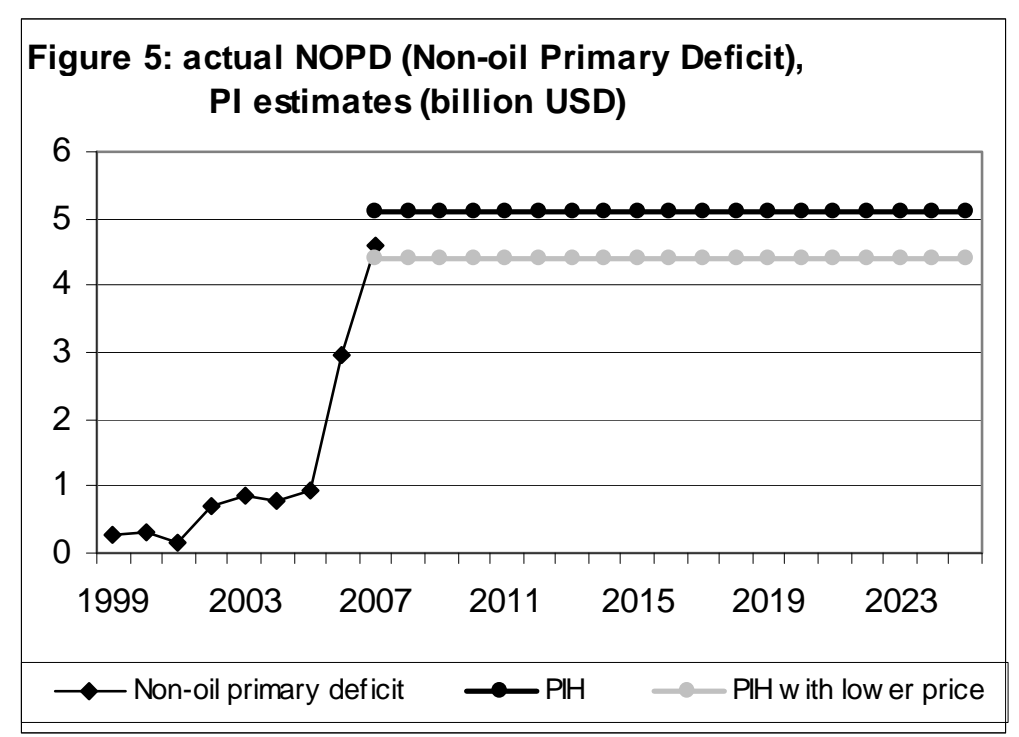

The PI estimates should be compared to the non-oil primary deficit (NOPD), as the NOPD represents the net claim on non-oil resources, to be covered by the PI amount transferred from the Oil Fund (cf fig.5). Current spending plans are thus close to the PI estimates, but consistently above it. Therefore, some degree of caution is called for, particularly if further increases in non-oil deficits were to follow the large increases in 2006 and 2007.

\section{Managing Uncertainty: Scenarios}

We present three illustrative fiscal strategies for the non-oil deficit to GDP ratio NOPD (see Fig. 6 below ). First, a base case scenario, which is guided by the medium term fiscal framework used by the Azeri Government before the PI calculations were made. This 
base case, envisages non-oil primary deficits in excess of its PI equivalent estimate to accommodate high infrastructure requirements. Thereafter, public spending is assumed to decline slightly, remain at about 30 percent of GDP during 2011-2015, and decline further afterwards, reaching 22 percent of the non-oil GDP by 2040. The non-oil revenues to GDP ratios are projected to increase gradually from current 11.2 percent in 2007, reaching 18 percent of GDP by 2015, remaining at 18 percent of GDP thereafter. The resulting NOPD increases initially, reaching nearly 21 percent of GDP during the next three years, but then declines and reaches 12 percent by 2015, and after some additional adjustment, reaches about four percent of GDP by the end of the projection period.

Second, a PI strategy, which assumes that the non-oil deficits are bounded by the "permanent income" rule and the associated flow of oil revenue to the budget. One implication of this rule is that because the economy will be growing, non-oil deficit to GDP ratios will decline in the future. This is a reasonable sharing rule since over-all GDP growth is projected to be based, not on population growth, but on capital accumulation and productivity growth. Constant real amounts with a constant population imply equal amounts (in real terms) for current and future generations on a per person basis.

\section{Figure 6. Illustrative fiscal strategies for managing oil windfalls}

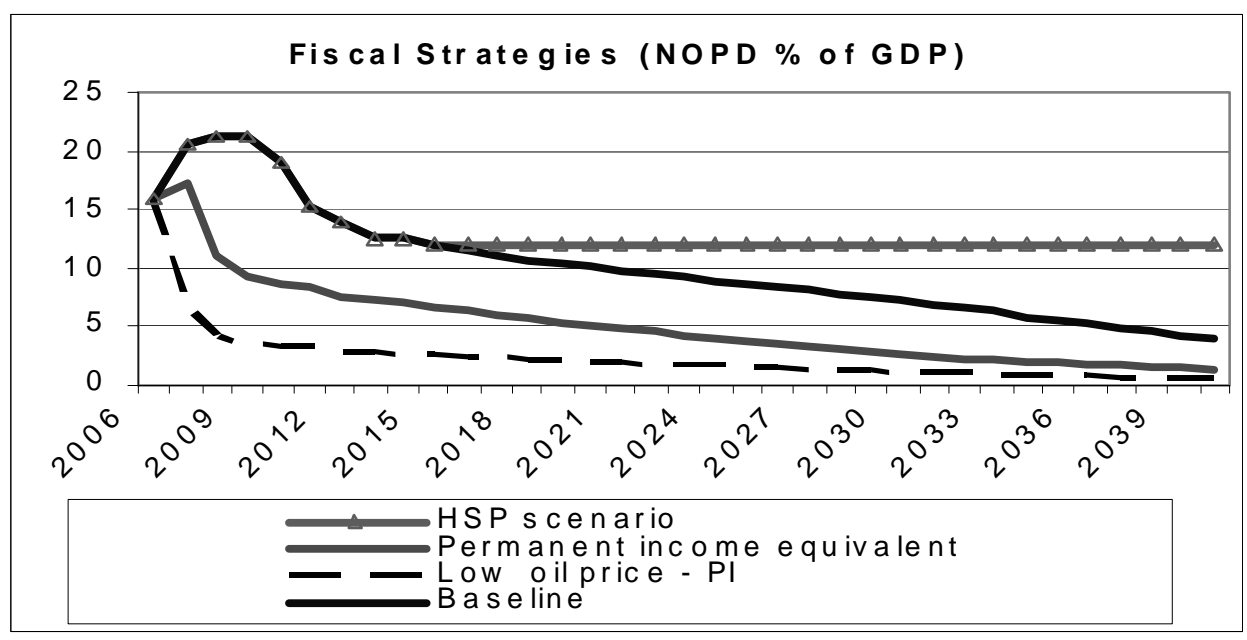

Finally, we also specify a "high spending" scenario, whereby public spending increases like in the base case for the next three years, but as opposed to the decline decline envisaged in the base case, public spending remains at its 2010 level (30 percent of GDP). 
Provided that the non-oil revenue remains the same as in the base case, this implies a constant non-oil deficit of 12 percent of GDP from 2015 onwards (see Figure 6).

With the different fiscal strategies specified, we run the fiscal sustainability model to derive baseline projections for net public debt throughout the projection period. Note that this framework also incorporates the dynamics of the Oil Fund assets and an Oil Fund rule governing the funding made available from the fund to the regular budget.

Figure 7: Stress tests for the Net Debt/GDP ratio

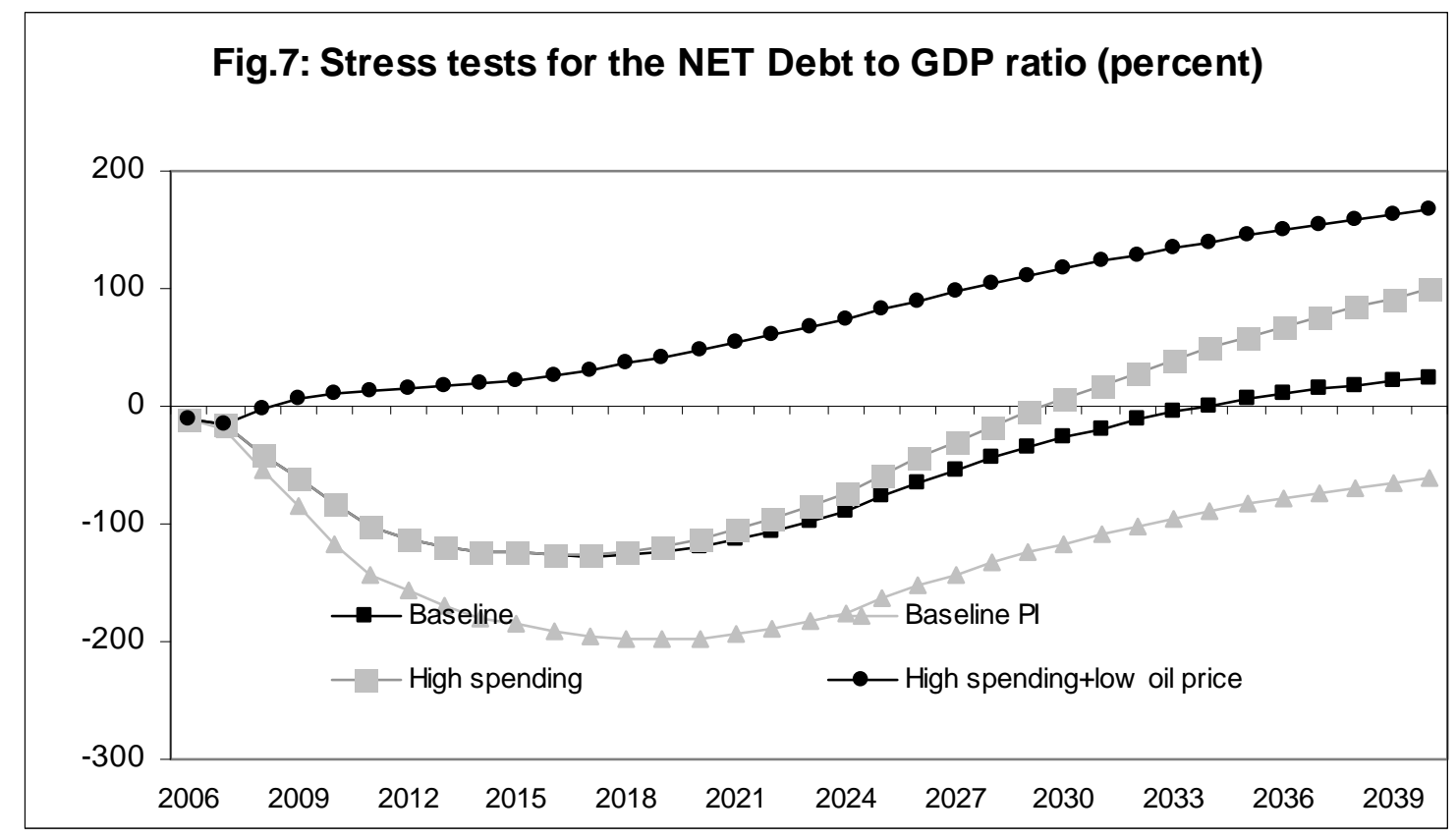

In Fig. 7, we present the results for the different fiscal strategies: base case, PI, and high spending (HSP). The diagram shows the net debt to GDP ratio, including the OSF as a negative item, under the various spending programs, derived in a non-stochastic projection. The starting point is a negative number: the Oil Fund and other FX assets exceed the gross public debt by a substantial margin in 2007 , for a net debt position of $-10 \%$ of GDP. Given the hump-shaped profile of the oil revenues within the next 20 years, and assuming the baseline fiscal strategy, Azerbaijan is to accumulate sizeable net financial assets by 2015 (negative net debt implies a positive net asset position). Once the oil windfall starts to dissipate, the baseline fiscal strategy would imply running down of the net assets. At the end of the planning horizon, Azerbaijan has eaten up its OSF and the other FX assets it started 
out with, and reaches a zero net debt position. After that, Azerbaijan will fall into debt again, since the nopd by that time, exceeds oil revenues (see fig.6 and fig.7).

Under the PI scenario, sustainability is, of course, not under threat because it is explicitly designed as a sustainable strategy; the net debt position remains basically unchanged over the planning horizon. Initial net savings are positive as oil revenues exceed the transfer of the PI equivalent to the budget. Later, the PI equivalent transfers start exceeding oil revenues as the latter decline, but the overall net debt position remains essentially stable since the transfers from the OSF to the budget can now be funded from OSF investment return income.

Under the "high spending" scenario HSP, primary spending is maintained at 30 percent of GDP, with a corresponding non-oil primary deficit - at 13 percent of GDP. The net asset position deteriorates and reaches zero in 2030. Thereafter, Azerbaijan becomes a net debtor again, to reach a net debt of 90 percent by 2040, a deterioration of no less than 80 percentage points of GDP. Finally, we introduced a worst case scenario, equal to the HSP run but with much lower oil prices. Specifically we assumed that the oil price would fall to its (very) long term average of 35 constant 2007 US\$ per barrel. Not surprizingly given the outcome of the HSP scenario, Azerbaijan turns into a net debtor very quickly as high spending is maintained in the face of falling ouil prices, and debt escalates rapidly after that.

\section{Managing Uncertainty: Monte Carlo (MC) Simulations}

Scenarios that seem reasonable in expected value terms may, nevertheless, mask substantial risks. We therefore implement a V@R approach to public debt. We do that by running full-scale Monte Carlo simulations, using historical variances of the variables being simulated, as well as by simulating the full probability distribution of future debt/output ratios. We then plot the distributions resulting from the stochastic simulation in a so-called "fan chart" for the debt-to-GDP ratio. For the shocks, we concentrate on two key variables, changes in the real exchange rate, and the price of oil. We first use fiscal rules (PI rules or otherwise) that do not respond to the simulation outcomes. It will become clear that such rules introduce considerable uncertainty in the sense that the resulting distributions become very wide (i.e., the long-term risks are large). We then show that even modest feedback from higher debt levels to higher surpluses reduce that uncertainty to a considerable extent. 
In the first graph (Fig.8) we show the distribution of future debt levels over time in the base case. The results show widely dispersed distributions, as a reflection of the very high variance prevailing in the past: in the MC simulations we assumed historically recorded variances would persist. . The runs reflect the baseline outcome, a net asset position that evaporates as time goes by. in about 30 years, Azerbaijan is expected to become a net debtor, once again, under this scenario. Moreover, based on historical variances and the complete lack of any feedback of rising debt levels on fiscal policy, the net debt position can become very large over the next three decades. With $95 \%$ certainty, we can only say that the net debt will not become greater than $100 \%$ of GDP over the simulation horizon, indicating that the risk of major debt problems is very real under this strategy. One response would be to introduce feedback strategies: if net debt rises faster than planned, a larger non-oil surplus is implemented. We will explore such strategies in the next section. But, first, we will show what happens under the PI strategy.

Figure 8. Distribution of future debt stocks under the base line scenario.

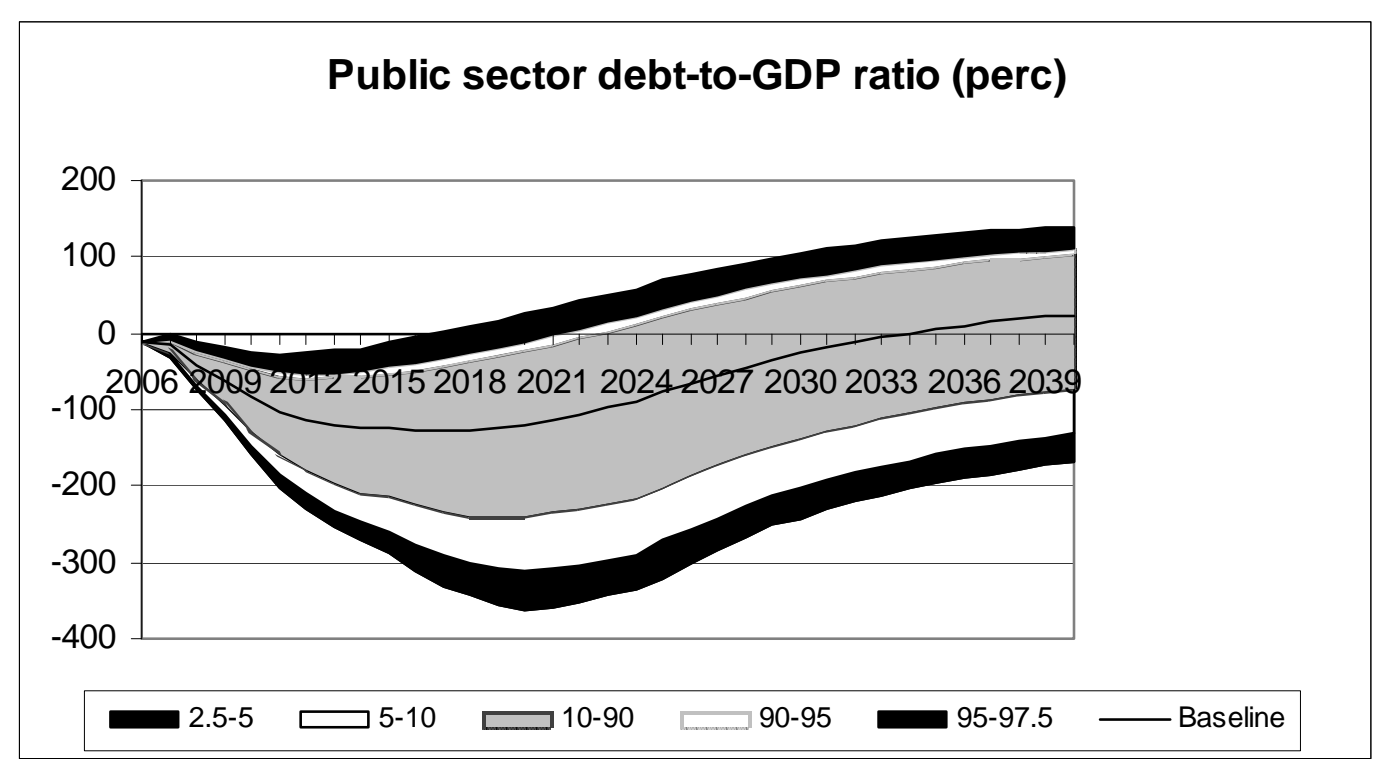

We run two variants: one using historical variances for both variables being simulated (Fig. 9), and one where the variance of the real exchange rate is reduced by $50 \%$, reflecting the fact that this run has a more stable expenditure policy (Fig. 10 below. 
Figure 9 Distribution of future debt stocks under the PI scenario at historical variances.

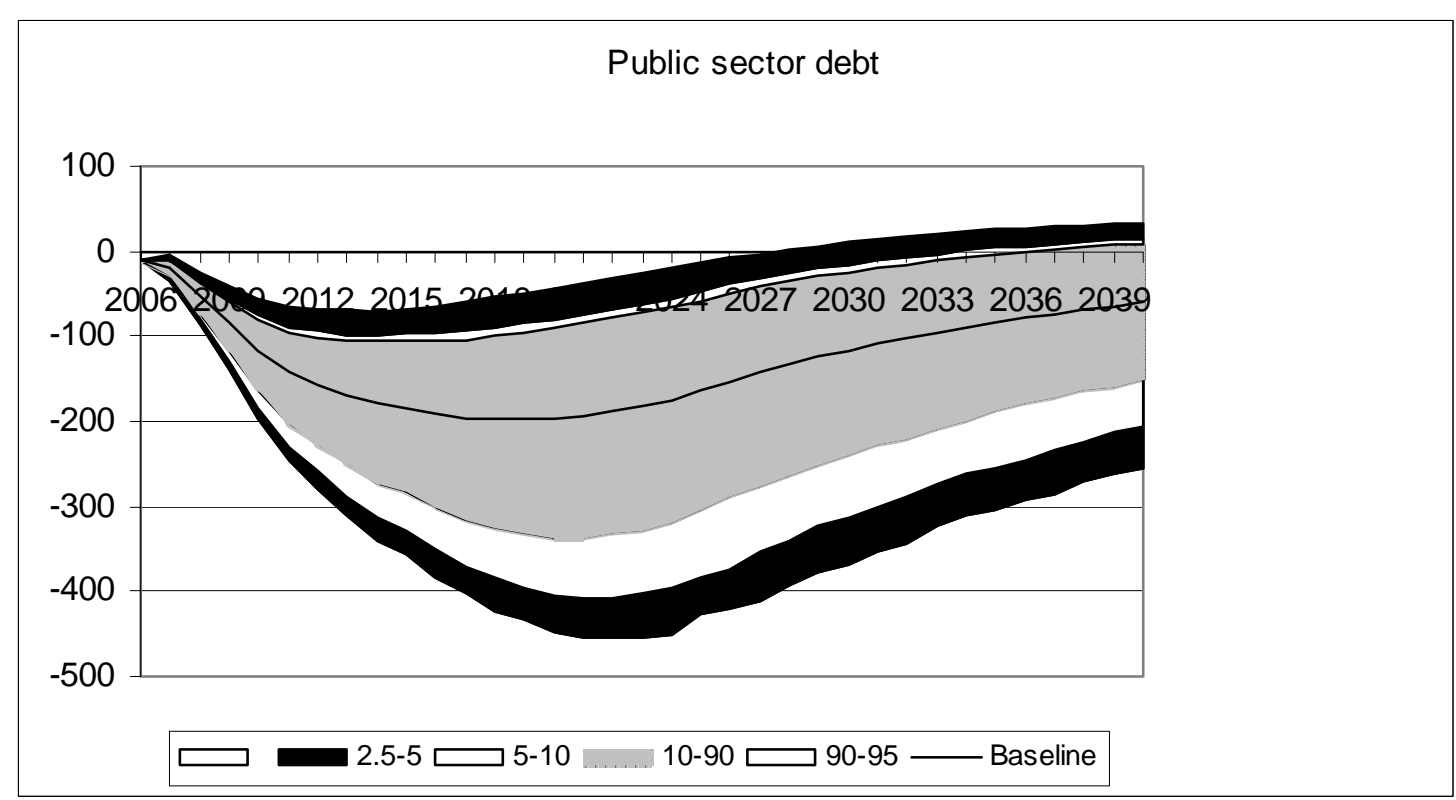

The central path in the historical variances case equals the deterministic projection, by construction, where Azerbaijan is expected to stay in a positive net assets position over the entire horizon. But the high variance used in the runs demonstrates that there is a significant possibility that Azerbaijan will turn into a net debtor anyhow.

Figure10 PI scenario at historical oil price variance and at $50 \%$ of historical variance for rer

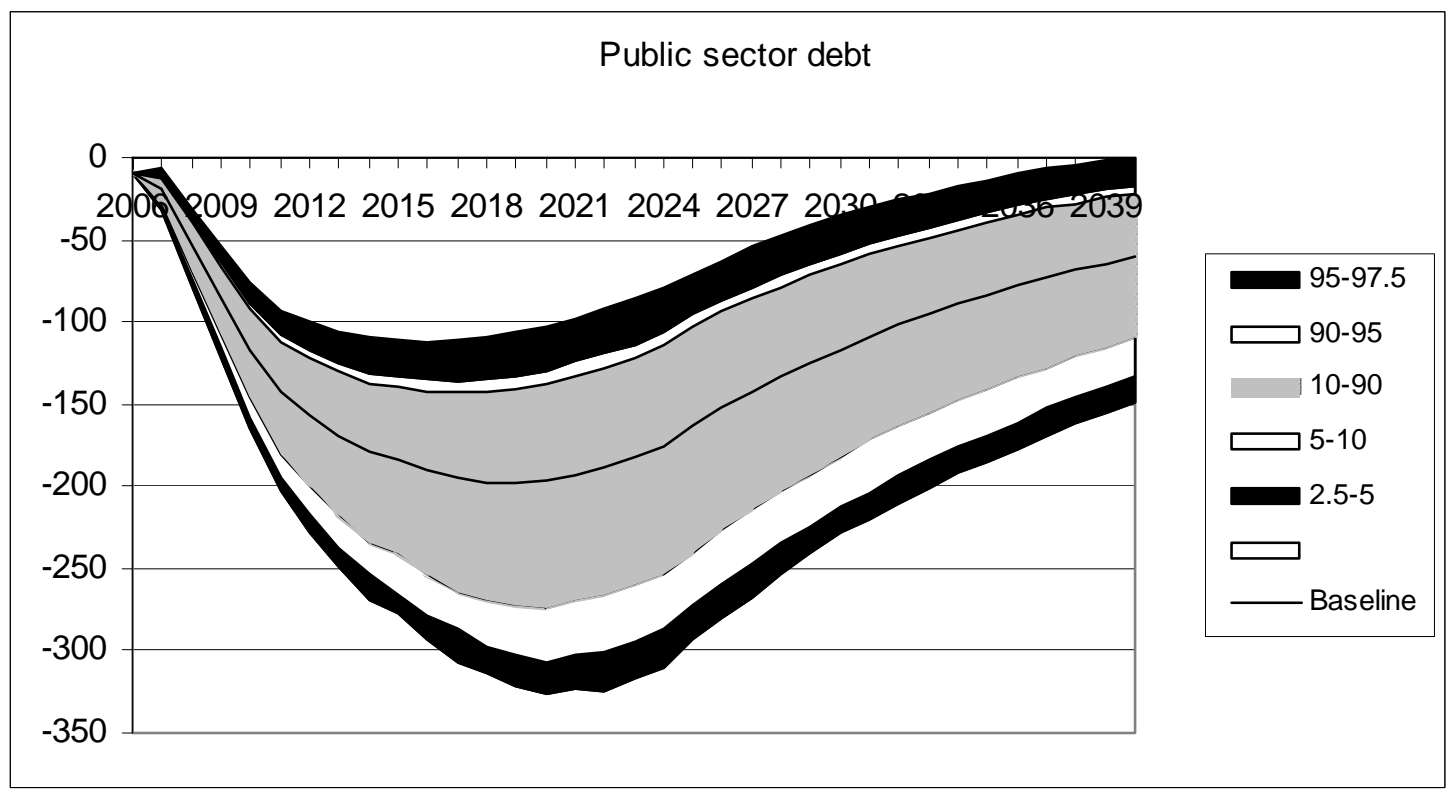


The simulations summarized in Fig.10 show that reduced real exchange rate variance has a major impact on the fanchart of future debt ratios: the width of the $95 \%$ range now falls from 250 to an admittedly still wide 140 percent of GDP, with further gains likely once a debt feedback rule is adopted. In the Fig. 10 scenario, Azerbaijan will with more than 95\% certainty, stay out of debt during the entire simulation period.

However, under the "high spending" scenario, the debt situation seriously gets out of hand (Figure 11 below). The expected value (black middle line) shows that debt levels are likely to reach some $100 \%$ of GDP, as in the non-stochastic projections of section IV. But the stochastic simulation shows that it could well run up much higher than that. All we can say is that with $95 \%$ certainty, the net debt level will stay below $200 \%$ of GDP in the simulation period, clearly an unacceptable level of debt once oil has run out. Of course, this assumes that high spending will be maintained throughout the simulation period and throughout all random shocks, without any feedback from negative surprizes to fiscal policy. Clearly, the "high spending" scenario exposes Azerbaijan to major risks.

Figure 11 Distribution of future debt stocks under the "high spending” scenario.

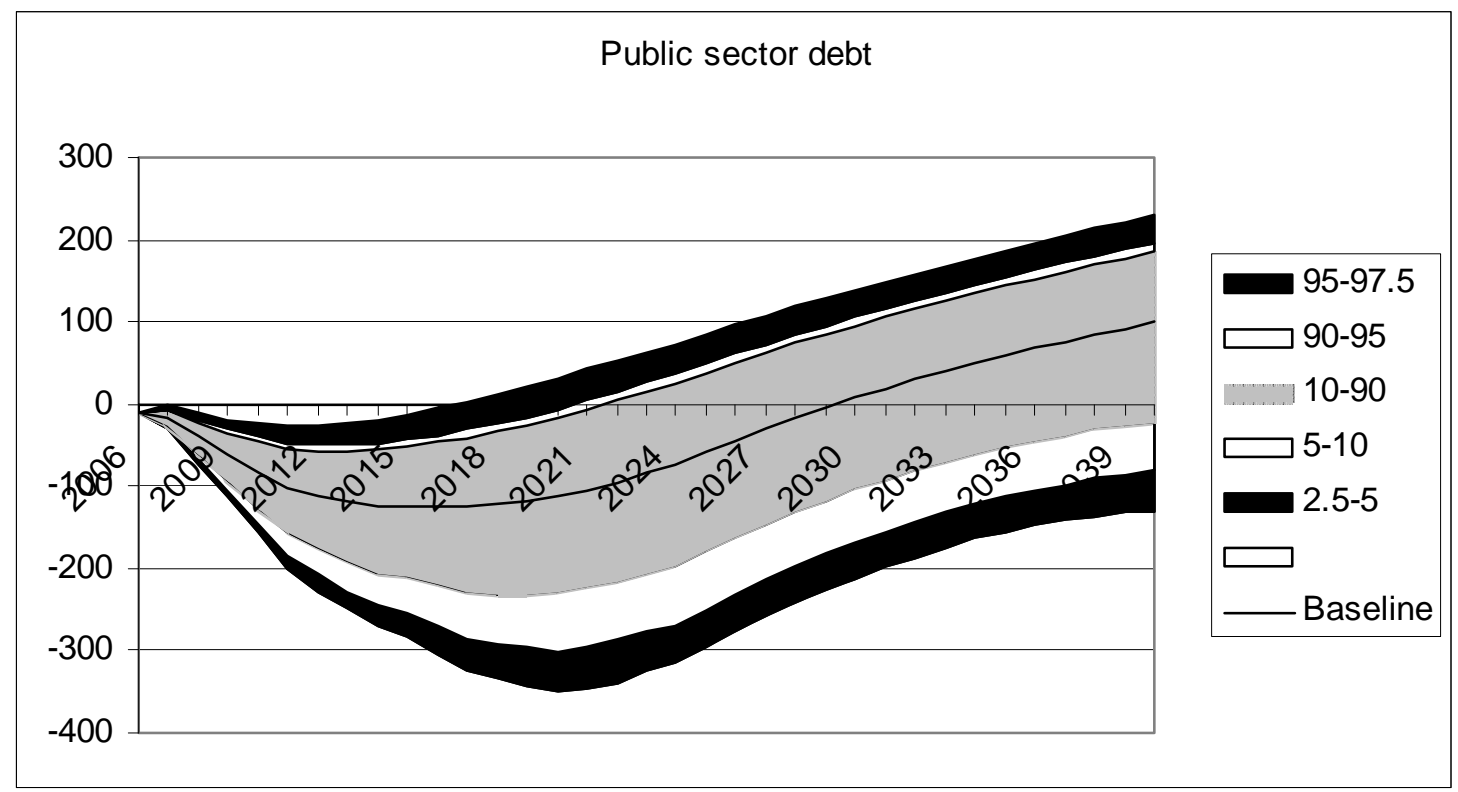

Fiscal feedback rules

All simulations presented so far assume a fixed fiscal rule, for example, a primary non-oil deficit equal to the ex-ante calculated permanent income level of oil revenues. The lack of any ex-post response to adverse shocks accommodates massive uncertainty about 
future debt stocks. This matters a great deal: default risk premia will depend on the likelihood that debt levels are larger than a threshold level beyond which political problems will block debt service (cf. Schabert and van Wijnbergen (2006, 2010), or Reinhard and Rogoff (2003) for empirical evidence). Although we do not know those thresholds, for any given value of such a threshold, greater uncertainty about future debt levels implies a greater probability of a future crisis.

Figures 12 and 13 show how a feedback of (unanticipated) higher debt levels to larger primary surpluses leads to much less uncertainty about future debt stocks . Figure 12 simply reproduces the simulation results already reported in Fig. 10. There, we assumed that the non-oil primary deficit equals the permanent income value of oil revenues, and that the increased stability of spending would reduce the variance of the real exchange rate by $50 \%$. Although Azerbaijan can be said, with $95 \%$ certainty, to stay out of net debt, there still is a very wide range of expectations about future debt stocks.

Figure 12. PI spending, historical oil price variance, $50 \%$ of historical RER variance.

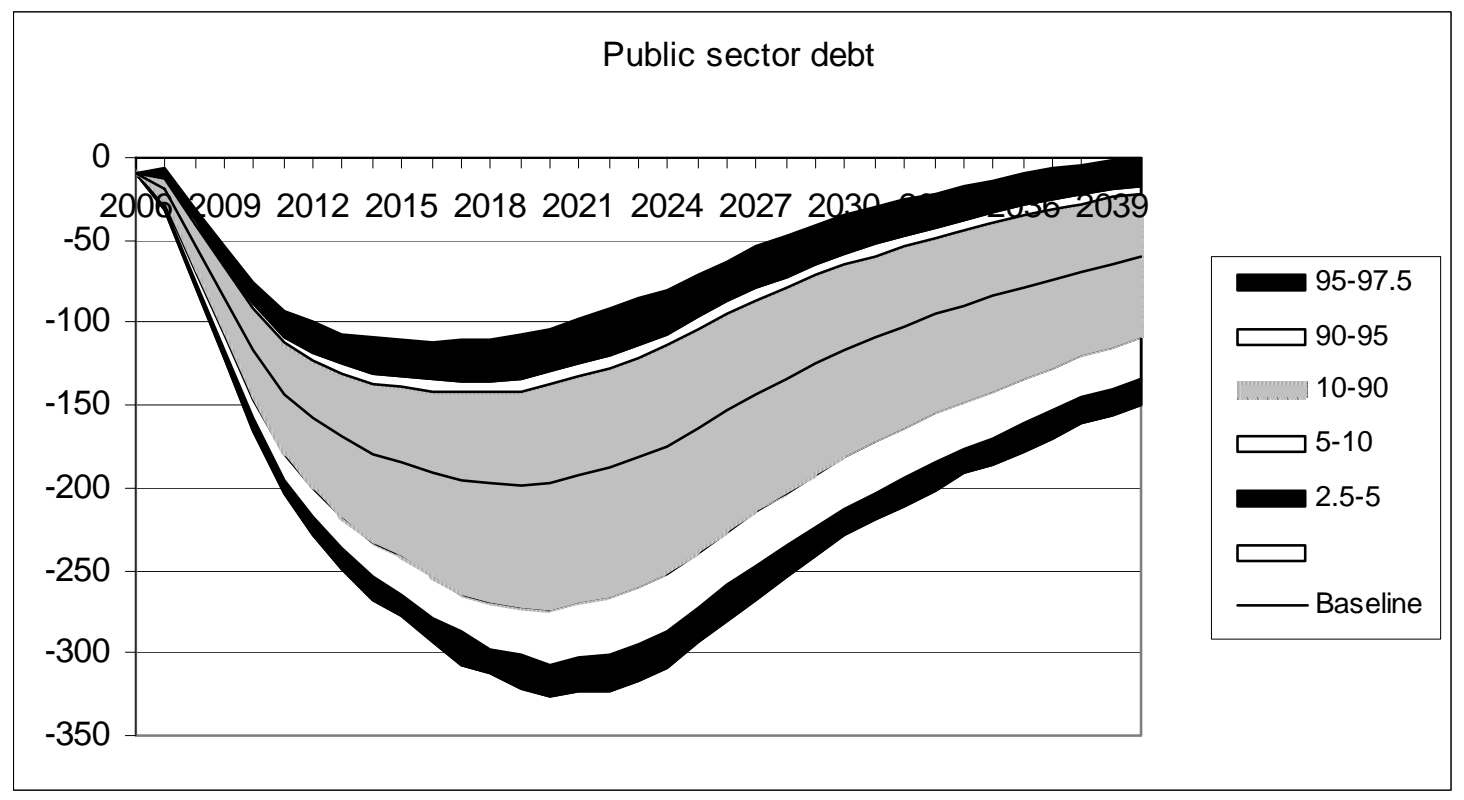

Next, we assume a feedback rule from higher than anticipated debt stocks to a stricter fiscal policy (cf equation (1.12)): a linear feedback rule where a percentage of last year's excess debt (higher than projected in the base run for given NOPD assumptions) is offset by a lower non-oil primary deficit. Budina and van Wijnbergen (2007) show that Turkey, throughout the nineties, used a strong feedback rule, with a feed back coefficient of 0.20 (i.e., 
$20 \%$ of any debt surprise was corrected the following year by tightening fiscal policy). If we add such a feedback rule to the simulations of fig.12, we get Fig. 13.

\section{Figure 13. PI spending, historical oil price variance, $50 \%$ of historical RER variance, and a "debt feedback rule", ALPHA = 0.2.}

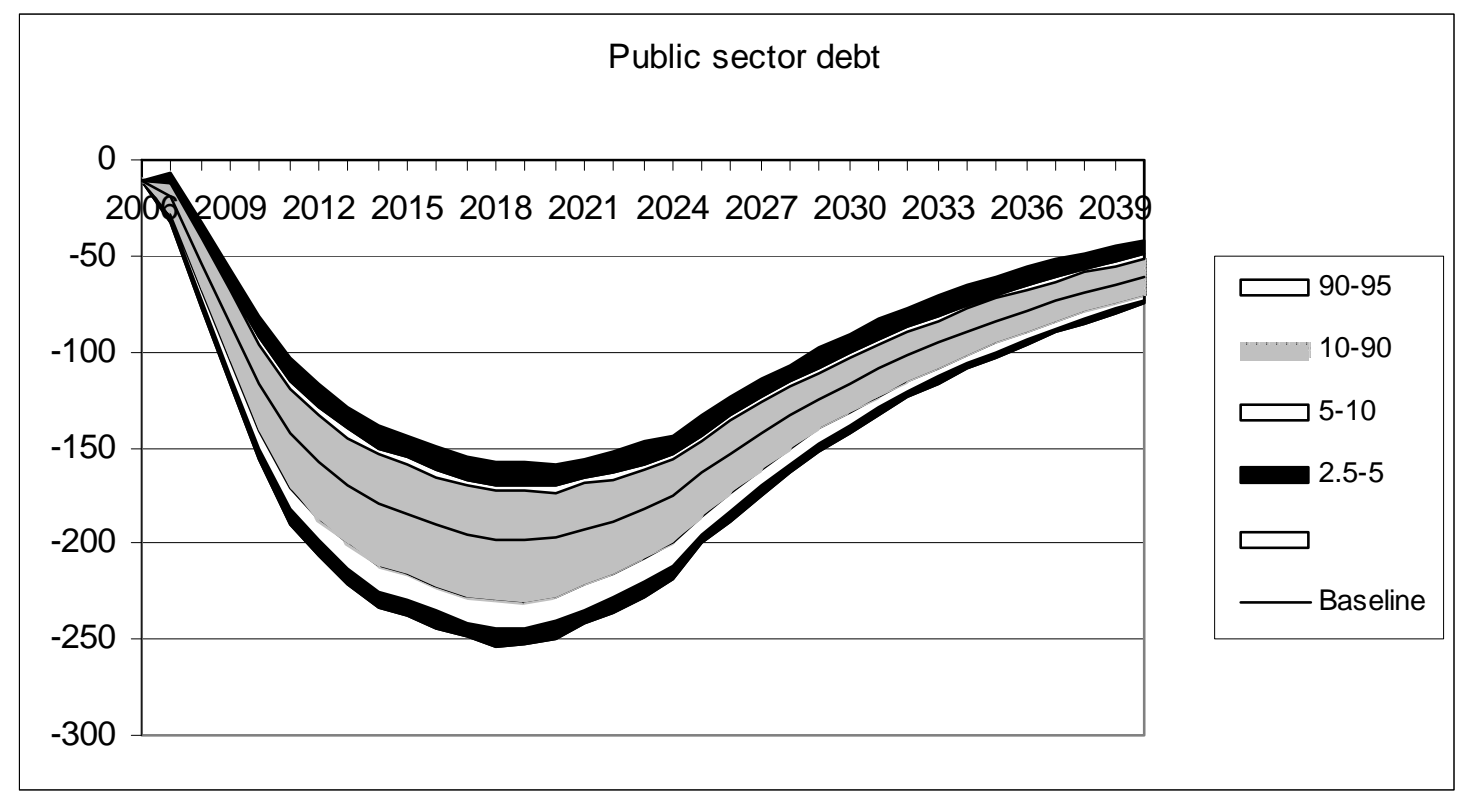

The simulations show a dramatically improved outlook. While the expected value of future debt stocks (the black line in the middle) is not affected, the distribution around that line narrows dramatically. The $95 \%$ worst outcome line now stays at a positive net assets position of $40 \%$ of GDP, instead of touching zero. The range between the $95 \%$ worst outcome and $95 \%$ best outcome narrows down to about 30 percentage points of those in 2040, down from a high 140\% of GDP. The results are very clear: such a feedback rule, while not raising the average burden of fiscal policy, will greatly reduce estimated crisis probabilities by reducing variance in the economy.

\section{Conclusions}

Commodity exporters face major challenges managing their often highly volatile and often only temporary natural resource wealth. Because of the temporary nature of for example oil and gas revenues, intergenerational fairness is a major issue. And when the oil boom ends when oil runs out, there are legitimate concerns about post-oil economic 
performance (Dutch Disease issues). Finally, the highly volatile nature of oil revenues adds further policy challenges; if it were to translate into highly volatile spending levels and associated volatility of the real exchange rate, the impact would be like a tax on private investment, with negative consequences for economic growth.

In this paper, we argue that explicitly adopting a permanent income approach to the decision on how much to spend out of oil revenues provides an adequate response to all three issues. In our case study of Azerbaijan, the baseline simulations have non-oil deficits initially at budgeted levels, but eventually increase substantially once oil wealth starts decling, In those scenarios, Azerbaijan emerges as a net debtor in the relatively near future. This happens even sooner if spending levels do not decline as budgeted in the base case. The worst scenario of all, high spending but with low oil prices, where oil prices would collapse to their historical average of about $\$ 35$ dollars in prices, will see clearly unsustainable levels of net debt emerge very soon. But, limiting the net claim on resources by the public sector (the non-oil primary deficit) to the permanent income equivalent of Azerbaijan's oil wealth will result in sustainable spending programs. Under this scenario, Azerbaijan is not expected to run into a net debt position at any time during the projection period.

Of course, such simulations do not reflect the uncertainty that dominates future outcomes. Therefore, we ran stochastic simulations deriving the entire distribution of future debt stocks based on the historical variances of the simulated driving variables. In particular, we looked at shocks in oil prices and the real exchange rate. What stands out is that future debt levels are characterized by a very wide distribution as uncertainty cumulates. This point is pivotal: projections of crises will depend on the likelihood that critical debt levels will be exceeded. The wider the distribution of future debt stocks around a given baseline, the greater the associated estimates of crisis probabilities, even if the baseline itself were to stay below any crisis trigger level. We show that under all but the PI scenarios, in a variant on the Value at Risk approach used by commercial banks, the maximum net debt levels that can be expected with $95 \%$ confidence reach as high as 100 percent of GDP under the baseline scenario. Under the high spending scenario, the 95\% certainty maximum debt level even exceeds $200 \%$ of GDP, a clearly unsustainable level. Thus, these scenarios expose Azerbaijan to considerable economic risk. 
The PI approach reduces that risk substantially. If we also reasonably assume a reduced variance of the real exchange rate in response to more stable expenditure patterns, we can say, with 95\% certainty, that Azerbaijan will remain debt-free for the entire simulation horizon, thereby essentially reducing crisis probabilities to zero.

Finally, the assumption made in the stochastic simulations, that there would be no feedback from higher-than-expected debt stocks to the non-oil primary deficit, was replaced in the final section by an active feedback loop. Under this extension to fiscal policy, targets for deficits are complemented by targets for debt, and any excess of debt over that target path results in a deficit reduction equal to a given percentage of the excess debt stock of the previous year. We have simulated the impact of a feedback loop with a high correction percentage of $20 \%$, equal to the empirical estimates obtained for Turkey, simply as an example. Such a feedback policy leads to a dramatic narrowing of the range in which future debt stocks will most likely remain. In particular, under the PI scenario, there is a 95 percent chance that net assets will remain at 20 percent of GDP or higher. .

The conclusion should be obvious. It is highly advisable to combine whatever fiscal deficit strategy is chosen with (a) implied target levels for net debt, and (b) a rule that any excess over that target level will result in a smaller non-oil deficit during the next period by a given percentage of that excess. This should have a strong impact on confidence; while such a rule does not affect the average spending level of the government, it will greatly reduce the variance of debt outcomes, which should lower crisis expectations. This, in turn, should translate into lower costs of debt servicing and less volatility in the capital account.

\section{References:}

Aghion, Ph., Ph. Bacchetta, R. Ranciere, and K. Rogoff (2009), "Exchange rate volatility and productivitygrowth: the role of financial development.", Journal of Monetary Economics, 56, pp. 494-513, 2009.

Anand, R. and S. van Wijnbergen (1989), "Inflation, and the Financing of Government Expenditures: an Introductory Analysis with an Application to Turkey", World Bank EconomicReview Volume 3, Issue 1, pp. 17-38.

Barnett, S. and R. Ossowski (2002), Operational Aspects of Fiscal Policy in Oil-Producing Countries, IMF WP/02/177 and chapter 3 in Fiscal Policy Formulation and Implementation in Oil-producing countries, edds. J. Davis, R. Ossowski and A, Fedelino, IMF, 2003. 
Baunsgaard, T. (2003), Fiscal Policy in Nigeria: Any Role for Rules, IMF WP/03/155.

Bohn, H. (2007), "Are Stationarity and Cointegration restrictions really necessary for the intertemporal budget constraint?" Journal of monetary Economics, vol. 54, pp $1837-1847$.

Budina, N. and S. van Wijnbergen (2007): "Debt, Deficits and Inflation in Turkey: Is there a Fiscal Dominance Problem?" mimeo, University of Amsterdam.

--------- (2008), "Managing Oil Revenue Volatility in Nigeria: The Role of Fiscal Policy", in Delfin S. Go and John Page (eds.), Africa at a Turning Point? Growth, Aid, and External shocks, Oxford University Press, 2008.

Caballero, R. and G. Lorenzoni (2007), "Persistent Appreciations and overshooting: a Normative Analysis," NBER WP 13077.

Chalk, N.. 1998. "Fiscal Sustainability with Non-Renewable Resources.” IMF WP/98/26.

Collier, P., R. van der Ploeg, M. Spence and A. Venables (2010), "Managing resource Revenues in Developing Countries", IMF Economic review, vol. 57, pp 84-118.

Davoodi, H. (2002), Assessing Fiscal Vulnerability, Fiscal Sustainability, and Fiscal Stance in a Natural Resource Rich-Country, in: in Republic of Kazakhstan, Selected Issues and Statistical Appendix, International Monetary Fund, Country Report No.02/64, March.

Engel, E. and R. Valdes (2000), Optimal Fiscal Strategy for Oil Exporting Countries, IMF Working Paper WP/00/118.

International Monetary Fund (2003), "Public Debt in Emerging Markets," World Economic Outlook, October, September 2003, IMF, Washington DC.

International Monetary Fund (2005), "Information Note on Modifications to the Fund's Debt Sustainability Assessment Framework for Market Access Countries," SM/05/250, Washington DC.

International Monetary Fund and International Development Association (2005), "Operational Framework for Debt Sustainability Assessments in Low-Income Countries-Further Considerations," SM/05/109, Washington, DC.

Liuksila, C., A. Garcia, and Sheila Bassett (1994), "Fiscal Policy Sustainability in OilProducing Countries," IMF WP/94/137.

Reinhard, C., K. Rogoff and M. Savastano (2003), Debt Intolerance, Brookings Papers on Economic Activity, vol.1, pp 1-62 
Schabert, a. and S. van Wijnbergen (2006), "Debt, Deficits and Destabilizing Monetary policies in Open Economies", Tinbergen Institute Working paper, University of Amsterdam, TI 2006-045/2.

Schabert, A. and S. van Wijnbergen (2010), "Sovereign default and the stability of inflation targeting regimes", Tinbergen Institute Working paper nr. TI 11-064, University of Amsterdam,

Wijnbergen, Sweder van (1984a), “The Dutch Disease: A Disease after all?" Economic Journal, Volume 94, Issue 373 (March), pp: 41-55.

--- (1984b), "Inflation, Employment and the Dutch Disease in Oil Exporting Countries: A Short-Run Disequilibrium Analysis", Quarterly Journal of Economics, Volume 99 (1984), Issue 2 (May), pp: 233-50.

--- (2008), “The Permanent Income Approach in Practice: A Policy Guide to Sustainable Fiscal Policy in Azerbaijan," mimeo, University of Amsterdam.

Annex 1: feedback rules and variance reduction ${ }^{6}$

We collapse all possible stochastic shocks into a single shock to the primary deficit $d_{t}{ }^{7}$

$$
\begin{aligned}
b_{t} & =d_{t}+(1+r) b_{t-1} \\
d_{t} & =\bar{d}_{t}+\varepsilon_{t} \\
& \Rightarrow b_{t}=\bar{d}_{t}+\varepsilon_{t}+(1+r) b_{t-1}
\end{aligned}
$$

$\bar{d}_{t}$ is the non-stochastic part of the deficit process. Define $b_{t}^{\tau}$ as the (stochastic) projection of $b$, constructed at time $t$, for $\tau$ periods ahead. If the shocks to $d_{t}$ are i.i.d. with constant variance $\sigma$, the variance of this projection equals:

${ }^{6}$ Available on request from the second author, S.J.G.vanwijnbergen@uva.nl

${ }^{7}$ For the formulas to hold, $\mathrm{d}$ and $\mathrm{b}$ can refer to nominal or real deficits and debt, or ratios to GDP, as long as the inrterest rate $r$ is defined correspondingly (nominal, real or real growth adjusted respectively). 


$$
\begin{aligned}
\operatorname{var}\left(b_{t}^{\tau}\right) & =\operatorname{var}\left(\sum_{t^{\prime}=1}^{t^{\prime}=\tau} \varepsilon_{t^{\prime}}(1+r)^{t^{\prime}-1}\right) \\
& =\sigma^{2} \sum_{t^{\prime}=1}^{t^{\prime}=\tau}(1+r)^{2\left(t^{\prime}-1\right)} \\
& =\sigma^{2} \frac{(1+r)^{2 \tau}-1}{(1+r)^{2}-1}
\end{aligned}
$$

where without loss of generality we assume a constant real rate of interest $r$. Consider next a fiscal feedback rule as proposed by Bohn (2007):

$$
d_{t}=\bar{d}_{t}+\varepsilon_{t}-\gamma \varepsilon_{t-1}
$$

The primary surplus now is subject to shocks, like in (1.15), but also contains a feedback reaction whereby a fraction $\gamma$ of the shock in the previous period is offset this period. Using the subscript "FR" and "NFR" for cases where there is respectively there is not such a feedback rule, it follows that:

$$
\begin{aligned}
\operatorname{var}\left(b_{t}^{\tau}\right)_{F R} & =\operatorname{var}\left(\sum_{1}^{\tau} \varepsilon_{t}(1-\gamma)(1+r)^{t^{\prime}-1}\right) \\
& =(1-\gamma)^{2} \sigma^{2} \frac{(1+r)^{2 \tau}-1}{(1+r)^{2}} \\
& =(1-\gamma)^{2} \operatorname{var}\left(b_{t}^{\tau}\right)_{N F R}
\end{aligned}
$$

Clearly a fractional offset coefficient $\gamma \subset(0,1)$ leads to variance reduction. Incidentally, (1.18) shows that $\gamma \subset(1,2)$ would also lead to variance reduction, but the resulting sawtooth pattern is presumably undesirable. Also, (1.18) does not depend on $\tau$, so it holds for all finite projection horizons and for asymptotic distributions. 